\title{
Review of "Pastoralism and Development in Africa: Dynamic Change at the Margins" edited by Andy Catley, Jeremy Lind, and lan Scoones
}

\author{
Mark Moritz
}

Correspondence: moritz.42@osu.edu

Department of Anthropology, The Ohio State University, 174 W 18th Avenue, Columbus, $\mathrm{OH} 43210$, USA

\section{Book details}

Catley, A, Lind J, and Scoones I, eds. 2013. Pastoralism and Development in Africa: Dynamic Change at the Margins. London: Routledge and Earthscan. Pp. 295. ISBN-13: 978-0-415-54071-1 (hardcover), ISBN-13: 978-0-415-54072-8 (paperback), ISBN-13: 978-0-203-10597-9 (e-book).

Keywords: Pastoral systems; Development; Greater Horn of Africa

\section{Pastoralism and development in Africa}

Pastoralism and Development in Africa is not the first, or likely the last, book on pastoral development and the future of pastoralism in Africa, which has been the subject of numerous books (e.g., Galaty et al. 1981, Sandford 1983, Scoones 1995), articles (e.g., Fratkin 1997), and online discussions (e.g., Sandford 2006). Because pastoral development has a long record of failure, I was kind of dreading reading yet another book on pastoral development coming forth out of a conference. However, I was happily surprised how well it synthesized current understandings of the complex dynamics of contemporary pastoral systems in the Greater Horn of Africa and how it outlined a new conceptual framework to think about pastoralism and development in the Horn.

This edited book is the product of an ongoing collaboration between the Future Agricultures Consortium (FAC) and the Feinstein Center of Tufts University in Addis Ababa, Ethiopia that included a conference on The Future of Pastoralism in Africa that was held in March 2011 in Addis Ababa. The contributions to the book Pastoralism and development in Africa were originally presented at the conference and are from researchers having a long-term engagement with pastoralists in the Greater Horn of Africa, which includes the countries of Sudan, South Sudan, Eritrea, Djibouti, Ethiopia, Somaliland, Puntland, Somalia, Kenya, Uganda, and Tanzania. The area is also referred to as the Horn of Africa or simply the Horn.

The contributions in the book are all relatively short and organized in four parts: 1) resources and production (i.e., the ecology of pastoral systems); 2) commercialization and markets; 3) land and conflict; and 4) alternative livelihoods. The chapters cover a wide range of topics, including: climate change (Ericksen et al.), land grabbing (Galaty, Nunow, Babiker), commercialization (Catley and Aklilu, Mahmoud, Abdullahi et al.), livelihood 
diversification (Fratkin, Livingstone and Ruhindi), and two chapters on irrigated agriculture (Sandford, Behnke and Kerven). The contributions are framed by an introductory chapter written by Andy Catley, Jeremy Lind, and Ian Scoones that outlines the conceptual framework of the book and a concluding chapter by Peter D. Little reflecting on the future of pastoralism in the Horn. In my review, I will focus primarily on these two chapters.

Pastoralism and Development in Africa is foremost an argument for the importance of pastoral systems and the economic contributions that pastoral systems make to the local, regional, national, and international economies. However, that does not mean that pastoralism is the only pathway to development in the region. Livelihood diversification is presented as a critical component of development in the Horn. After all the title of the book is not 'pastoral development' but 'pastoralism and development', meaning that that there are multiple developmental pathways in the Horn, one of them being pastoralism.

Development in this book also does not mean business as usual (Stockton 2012), i.e., large-scale projects funded by outside donors relying on modern technology. The failures of these conventional development projects are evident in the form of abandoned buildings across the Horn, particularly those that focused on improving livestock marketing. But while these large-scale, capital-intensive, infrastructural projects have failed, the informal livestock trade has grown steadily in the last decades and livestock trade in the Horn is now valued at hundreds of millions of dollars. However, this livestock trade is more or less 'invisible' as the infrastructure consists of livestock corridors, which are unmarked, and corrals, which are made of branches from acacia and other trees. The capital in this informal livestock trade is the human capital of the people involved, e.g., traders, intermediaries, and drivers. The difference between the failed conventional development driven by donors and the successful autonomous development driven by pastoralists is that between "seeing like a state" and "seeing like a pastoralist" (borrowing from Scott 1998).

\section{Conceptual framework: Seeing like a pastoralist}

The theoretical work of the political scientist James Scott $(1976,1998,2009)$ who has written extensively about Southeast Asian peasants and their relation with the state, is guiding the conceptual framework of Pastoralism and Development in Africa. This means that the book focuses on how pastoral peoples themselves develop, rather than how development professionals in New York, London, Rome, Nairobi, or Addis Ababa envision how pastoralists should develop. The editors argue in the introduction that pastoralists are not simply adapting; they are innovating. This is indicative of a conceptual shift in pastoralist studies from a systems approach to an actor approach. Rather than focusing on pastoral societies or pastoral systems, the analytical foci is on individuals and their innovative practices. Pastoralists are now seen as entrepreneurs resisting (as well as appropriating) the state's development efforts while simultaneously creating and pursuing new opportunities. In a sense, they are applying the pastoral principles and opportunity-seeking in contexts beyond the pastoral system (see also Simons 1995). In this analytical framework, individual pastoralists, working inside and outside the pastoral sector, have become active agents of change rather than passive recipients of development.

This focus on individual agents is somewhat of a departure from earlier work on pastoral systems in which the analytical focus was on societies, i.e., societies adapting to 
the ecology (cultural ecology, human ecology) or societies adapting to the larger political context (political ecology). In addition, while the book builds on a growing body of excellent, long-term research on the ecology of pastoral systems (e.g., Little and Leslie 1999), pastoral systems are now also explicitly studied using a regional approach in which pastoralists are integrated into regional and international markets that transcend pastoral groups and nations (see also McPeak, Little, and Doss 2011). The regional approach not only makes sense in terms of economic integration, but also in terms of political disintegration in that the consequences of civil war in one nation reverberate throughout the Horn.

While there is a shift from a systems approach to an actor approach, the editors emphasize that the larger context, including the insecurity problems and climate change, has to be considered. Pastoral entrepreneurs are facing enormous challenges, for example, how climate change will impact arid and semi-arid environments that are already challenging; the ongoing insecurity in the form of civil war, banditry, and intra- and intertribal raiding that plagues the Horn; as well as increasing competition for land and water in the arid and semi-arid areas of the Horn. Considering the larger ecological and political context, it is remarkable that pastoralism has been so persistent in the Horn.

The subtitle of the book, Dynamic Change in the Margins, refers to the idea that pastoralists are economically and politically at the margins of their respective states. That is why pastoralists are often deemed irrelevant, traditional, i.e., the antithesis of development from the perspective of the state and development organizations that work through the center. However, from a pastoralist's perspective the state is at the margins and the pastoral areas are the center. This is the perspective that the editors take. They view "the margins as the centre, borders as zones of exchange, and borderlands as sites of creativity and innovation in response to adversity" and argue that this offers an alternative vision of pastoral development, " although one that requires both new research methods and development practices" (page 14). More importantly, I would argue, it requires a new conceptual framework and I think that the ideas of "seeing like a pastoralist" and "seeing like a state" are very useful ways of thinking about pastoral development.

"Seeing like a state" and "seeing like a pastoralist" are not just two different ways of thinking about pastoralism and development. These two ways of seeing also conflict with each other and have real consequences for pastoralism in the Horn. For example, while pastoralists in the Horn are integrated into regional, national and international livestock markets that reach millions of consumers, most of the trade is informal and invisible, and even though its economic value is estimated at hundreds of millions of dollars, it is "not seen by the state" and not included in national figures like the GDP. This means that the pastoral sector is undervalued and this has implications for the willingness of national governments to invest in the pastoral sector. The consequences of invisibility also do manifest themselves in other ways. Behnke and Kerven, for example, argue in their contribution, which examines conflicting land uses of irrigated agriculture and pastoralism in the Awash Valley, that irrigated agriculture is not more productive than pastoral production systems. However, the big difference is that the irrigated agriculture is much more productive for the Ethiopian state which can tax the farmers and the export of agricultural products. This is in contrast to pastoralists and the livestock trade, which are more difficult to tax because of mobility of resources and the invisibility of the trade. 


\section{The future of pastoralism in Africa}

In the concluding chapter, Peter D. Little sketches his vision of the future of pastoralism in 2030. He argues that there likely will be a viable pastoral sector, but that it will be very different from today. In the arid and semi-arid areas of the Horn, livestock will continue to be the economic foundation (McPeak, Little, and Doss 2011) in part because of the so-called livestock revolution (Delgado et al. 1999), the idea that growing demand for livestock products will drive changes in animal productions systems across the world, including African pastoral systems. However, the livestock revolution may result in a different, more capital-intensive pastoral system aimed at production for the market (rather than for subsistence). While herd mobility remains critical in this capital-intensive system and family herders and hired herders will continue to move with their herds (some using trucks to move fodder, water and/or animals), pastoral families will settle in villages and towns where they have access to education and adults are employed in the broader livestock sector (e.g., marketing, transportation). Little's vision, and that of the editors and other contributors, of the future of pastoralism is one of a modern, dynamic sector in which pastoralists adapt in new and innovative ways to challenging political and ecological environments.

\section{Whole Africa?}

Finally, let me clarify that this is a book about pastoralism and development in the Horn of Africa; not about pastoralism and development in Africa as the title suggests. All the chapters in this book describe pastoral systems in the Horn with a few references to pastoral systems in other parts of Africa. The colonial powers divided the African continent at the end of the nineteenth century, but it continues to have a lasting impact on the study of pastoral systems, as Francophone scholars mostly study West African pastoral systems (with a few notable exceptions, e.g., Tom Bassett and Matthew Turner) and Anglophone scholars mostly study East African pastoral systems. And so in the Anglophone literature, West African pastoral systems are often viewed through the lens of pastoralism in the Greater Horn of Africa. This is problematic because West African pastoral systems, with which I am more familiar through my own research and reading of the literature, are different enough from those in the Greater Horn of Africa that is unclear how useful that lens or model is for understanding pastoral systems in other parts of Africa.

This also raises the interesting and important question about what a book about pastoralism and development in West Africa would be like. Surely, there are similarities between pastoral systems in West Africa and the Horn of Africa, but there are also considerable differences. The arid and semi-arid areas of West Africa have been described as a mosaic of types of land use, population densities, and market integration (Raynaut 2001), where pastoralists have been integrated into regional economies and agricultural systems for long (Ellis and Galvin 1994, Kerven 1992). Moreover, pastoralists in West Africa are not limited to the arid and semi-arid areas; they have successfully expanded into the sub-humid and humid zones too (Boutrais 1996). Finally, there is considerable diversity of pastoral systems ranging from highly-mobile, extensive systems to more sedentary, capital-intensive systems (Moritz et al. 2009). In short, West African pastoralists have long been well integrated into the local, regional, national, and international economies. One could argue that for a glimpse of the different 
alternative pathways for pastoralists in the Horn, it may pay off to look at what has been going on in West Africa in the last decades (Moritz et al. 2009).

\section{An ongoing conversation}

Pastoralism and Development in Africa is an ongoing conversation about pastoral development in the Horn of Africa that started with a conference, resulted in this book, and continues online with websites with additional materials hosted by the STEPS Centre (http://steps-centre.org/2012/uncategorized/pastoralism-and-development-inafrica-dynamic-change-at-the-margins/) and Future Agricultures (http://www.futureagricultures.org/events/future-of-pastoralism). I think this may be a more effective way to communicate research on pastoralism and development than only books. In that regard it is also important to note that Abebe Haile Gabriel, director of the Department of Rural Economy and Agriculture at the African Union Commission, writes in one of the book's blurbs that the African Union used central arguments from the book to develop the first continent-wide policy framework to support pastoralism in Africa. That is an exciting development, as policy makers have ignored pastoralists and experts on pastoral systems for long. I am glad to read that this seems to be changing.

Competing interests

The author declares that he has no competing interests.

Received: 28 June 2013 Accepted: 28 June 2013

Published: 22 July 2013

\section{References}

Boutrais, J. 1996. Hautes terres d'élevage au Cameroun, vol. 1-3. Collection études et thèses. Paris: ORSTOM Éditions.

Delgado, CL, MW Rosegrant, H Steinfeld, S Ehui, and C Courbois. 1999. The Coming Livestock Revolution. Choices: The Magazine of Food, Farm \& Resource Issues 14: 40.

Ellis, J, and KA Galvin. 1994. Climate patterns and land-use practices in the dry zones of Africa. BioScience 44: 340-9.

Fratkin, E. 1997. Pastoralism: Governance and development issues. Annual review of anthropology 26: 235-61.

Galaty, JG, D Aronson, PC Salzman, and A Chouinard (eds.). 1981. The future of pastoral people. Ottawa (Canada): IDRC.

Kerven, C. 1992. Customary Commerce: a historical reassessment of pastoral livestock marketing in Africa, vol. 15. ODI Agricultural Occasional paper. London: Overseas Development Institute.

Little, MA, and PW Leslie (eds.). 1999. Turkana herders of the dry savanna: ecology and biobehavioral response of nomads to an uncertain environment. Research monographs on human population biology. Oxford (UK): Oxford University Press.

McPeak, JG, PD Little, and CR Doss. 2011. Risk and Social Change in an African Rural Economy: Livelihoods in Pastoralist Communities. London: Routledge.

Moritz, M, B Kyle, KC Nolan, S Patrick, MF Shaffer, and G Thampy. 2009. Too Many people and Too Few Livestock in West Africa? An Evaluation of Sandford's Thesis. Journal of Development Studies 45: 1-21.

Raynaut, C. 2001. Societies and nature in the Sahel: ecological diversity and social dynamics. Global Environmental Change 11: 9-18.

Sandford, S. 1983. Management of pastoral development in the third world. Chichester (UK): John Wiley \& Sons.

Sandford, S. 2006. Too many people, too few livestock: the crisis affecting pastoralists in the Greater Horn of Africa. http://www.future-agricultures.org/pdf\%20files/Sandford_thesis.pdf. Accessed 25 May 2007.

Scoones, I. 1995. New directions in pastoral development in Africa. In Living with uncertainty: new directions in pastoral development in Africa, ed. I Scoones, 1-36. London: Intermediate technology publications.

Scott, JC. 1976. The moral economy of the peasant: rebellion and subsistence in Southeast Asia. New Haven (CT): Yale University Press.

Scott, JC. 1998. Seeing like a state: how certain schemes to improve the human condition have failed. Yale agrarian studies. New Haven (CT): Yale University Press.

Scott, JC. 2009. The art of not being governed. New Haven (CT): Yale University Press

Simons, A. 1995. Networks of dissolution: Somalia undone. Boulder (CO): Westview Press.

Stockton, G. 2012. Sugar for the tea: assistance and the state of pastoralism in the Horn of Africa. Pastoralism: Research, Policy and Practice 2: 6.

doi:10.1186/2041-7136-3-19

Cite this article as: Moritz: Review of "Pastoralism and Development in Africa: Dynamic Change at the Margins" edited by Andy Catley, Jeremy Lind, and lan Scoones. Pastoralism: Research, Policy and Practice 2013 3:19. 